University of Wollongong

Research Online

Australian Institute for Innovative Materials -

Papers

Australian Institute for Innovative Materials

$1-1-2014$

\title{
Tuning three-dimensional TiO2 nanotube electrode to achieve high utilization of Ti substrate for lithium storage
}

Zhijia Zhang

University of Wollongong, zz755@uowmail.edu.au

Qing-Yi Zeng

Chinese Academy of Sciences

Shulei Chou

University of Wollongong, shulei@uow.edu.au

Xinjun Li

Chinese Academy of Sciences

Huijun Li

University of Wollongong, huijun@uow.edu.au

See next page for additional authors

Follow this and additional works at: https://ro.uow.edu.au/aiimpapers

Part of the Engineering Commons, and the Physical Sciences and Mathematics Commons

Research Online is the open access institutional repository for the University of Wollongong. For further information contact the UOW Library: research-pubs@uow.edu.au 


\title{
Tuning three-dimensional TiO2 nanotube electrode to achieve high utilization of Ti substrate for lithium storage
}

\author{
Abstract \\ Three-dimensional (3D) TiO2 nanotube arrays grown on Ti mesh were prepared via the anodization \\ process. The diameters of the $\mathrm{Ti}$ and $\mathrm{TiO} 2 / \mathrm{Ti}$ wires and the length of the $\mathrm{TiO} 2$ nanotubes have linear \\ relationships with the anodization processing time. When the anodization processing time is $600 \mathrm{~min}$, the \\ TiO2/Ti mesh anode materials showed good capacity retention and high specific area capacity, without \\ the need for a current collector or binder, due to their high surface area, high substrate utilization, and \\ large active material loading rate per unit area. At the current density of $50 \mu \mathrm{A} \mathrm{cm}-2$, TiO2/Ti mesh with \\ $600 \mathrm{~min}$ anodization processing time has a stable discharge platform at $1.78 \mathrm{~V}$, and the specific area \\ capacity is $1745.5 \mu \mathrm{Ah} \mathrm{cm}-2$ over 100 cycles. By tuning the geometric parameters of the TiO2/Ti mesh \\ and the anodization processing time, we can pave the way to finding TiO2/Ti mesh electrodes for lithium- \\ ion batteries with high capacity per unit area and outstanding mechanical behaviour.
}

\section{Keywords}

substrate, three, lithium, dimensional, storage, achieve, tio2, ti, nanotube, utilization, high, electrode, tuning

Disciplines

Engineering | Physical Sciences and Mathematics

\section{Publication Details}

Zhang, Z., Zeng, Q., Chou, S., Li, X., Li, H., Ozawa, K., Liu, H. \& Wang, J. (2014). Tuning three-dimensional TiO2 nanotube electrode to achieve high utilization of Ti substrate for lithium storage. Electrochimica Acta, 133 570-577.

\section{Authors}

Zhijia Zhang, Qing-Yi Zeng, Shulei Chou, Xinjun Li, Huijun Li, Kiyoshi Ozawa, Hua-Kun Liu, and Jiazhao Wang 


\section{Tuning three-dimensional $\mathrm{TiO}_{2}$ nanotube electrode to achieve}

\section{high utilization of Ti substrate for lithium storage}

Zhi-Jia Zhang ${ }^{1}$, Qing-Yi Zeng ${ }^{2}$, Shu-Lei Chou ${ }^{1}$, Xin-Jun $\mathrm{Li}^{2}$, Hui-Jun $\mathrm{Li}^{3,{ }^{*}}$, Kiyoshi Ozawa ${ }^{4}$, Hua-Kun Liu ${ }^{1}$, Jia-Zhao Wang ${ }^{1, *}$

${ }^{1}$ Institute for Superconducting and Electronic Materials, University of Wollongong, Wollongong, NSW 2522, Australia,

${ }^{2}$ Key Laboratory of Renewable Energy, Guangzhou Institute of Energy Conversion, Chinese Academy of Sciences, Guangzhou 510640, P. R. China,

${ }^{3}$ Faculty of Engineering, University of Wollongong, Wollongong, NSW 2522, Australia,

${ }^{4}$ National Institute for Materials Science, Japan

*Corresponding author: jiazhao@uow.edu.au (JZW); huijun@uow.edu.au (HJL)

Phone: +61 242981478

Fax: $\quad+61242215731$ 


\begin{abstract}
Three-dimensional (3D) $\mathrm{TiO}_{2}$ nanotube arrays grown on $\mathrm{Ti}$ mesh were prepared via the anodization process. The diameters of the $\mathrm{Ti}$ and $\mathrm{TiO}_{2} / \mathrm{Ti}$ wires and the length of the $\mathrm{TiO}_{2}$ nanotubes have linear relationships with the anodization processing time. When the anodization processing time is $600 \mathrm{~min}$, the $\mathrm{TiO}_{2} / \mathrm{Ti}$ mesh anode materials showed good capacity retention and high specific area capacity, without the need for a current collector or binder, due to their high surface area, high substrate utilization, and large active material loading rate per unit area. At the current density of $50 \mu \mathrm{A} \mathrm{cm}{ }^{-2}, \mathrm{TiO}_{2} / \mathrm{Ti}$ mesh with $600 \mathrm{~min}$ anodization processing time has a stable discharge platform at $1.78 \mathrm{~V}$, and the specific area capacity is $1745.5 \mu \mathrm{Ah} \mathrm{cm}^{-2}$ over 100 cycles. By tuning the geometric parameters of the $\mathrm{TiO}_{2} / \mathrm{Ti}$ mesh and the anodization processing time, we can pave the way to finding $\mathrm{TiO}_{2} / \mathrm{Ti}$ mesh electrodes for lithium-ion batteries with high capacity per unit area and outstanding mechanical behaviour.
\end{abstract}

Key words: $\mathrm{TiO}_{2} / \mathrm{Ti}$ mesh, anodization, anode materials, lithium-ion batteries 


\section{Introduction}

Rechargeable lithium-ion batteries (LIBs) have been widely used as power sources for portable electronic devices due to their high energy-storage density, high voltage, long cycle life, and operation at ambient temperature [1-3]. Most of the commercial LIBs use graphitic carbon as the anode material. There are safety concerns about this material, however. Graphite electrode is prone to growing lithium dendrites after repetitive charge-discharge, resulting in irreversible damage to the lithium ion battery. Compared to graphite, $\mathrm{TiO}_{2}$ has a higher lithium intercalation potential $\left(1.75 \mathrm{~V}\right.$ vs. $\left.\mathrm{Li}^{+} / \mathrm{Li}\right)$, enabling it to avoid the deposition of metallic lithium, and it has higher capacity for $\mathrm{Li}^{+}$intercalation/de-intercalation $[4,5]$. These properties make $\mathrm{TiO}_{2}$ suitable for large-scale energy storage, when coupled with highvoltage cathode materials ( $\mathrm{LiMn}_{2} \mathrm{O}_{4}, \mathrm{LiNi}_{0.5} \mathrm{Mn}_{1.5} \mathrm{O}_{4}, \mathrm{LiNi}_{1 / 3} \mathrm{Mn}_{1 / 3} \mathrm{Co}_{1 / 3} \mathrm{O}_{4}$, etc.) [6-9]. Moreover, $\mathrm{TiO}_{2}$ is non-toxic, low-cost, abundant in nature, and has good electronic properties, as well as stable physical and chemical properties [10, 11].

Nanostructured $\mathrm{TiO}_{2}$ anodes have been successfully used to improve cycling stability and high rate capability over those of their bulk counterparts. Compared with nanoparticles, nanowires, and nanoribbons, self-organized $\mathrm{TiO}_{2}$ nanotube arrays possess larger specific surface areas and faster $\mathrm{Li}^{+}$transport [12-14]. The traditional $\mathrm{TiO}_{2}$ nanotube arrays, however, only have a low surface area and a small aspect ratio of length to diameter, because they are grown on $\mathrm{Ti}$ foil by electrochemical anodization and the length of $\mathrm{TiO}_{2}$ nanotube is only around $500 \mathrm{~nm}$, so the traditional $\mathrm{TiO}_{2} / \mathrm{Ti}$ foil electrode shows low area capacity $[5,15]$. Moreover, the use of $\mathrm{Ti}$ foil is expensive and wasteful. Liao et al. reported that only around 2 wt $\%$ of the $\mathrm{Ti}$ was converted into $\mathrm{TiO}_{2}$ nanotubes [16]. $\mathrm{TiO}_{2}$ nanotube array electrode grown on $\mathrm{Ti}$ mesh is a good choice to avoid these disadvantages. The $\mathrm{TiO}_{2}$ nanotubes extend radially in a $3 \mathrm{D}$ array on a grid of fine $\mathrm{Ti}$ wires, so the $\mathrm{TiO}_{2} / \mathrm{Ti}$ mesh electrode has high surface area, a large aspect ratio, and a high Ti conversion rate $\left(\mathrm{M}_{\mathrm{Ti}-1}\right.$ (Ti converted into $\mathrm{TiO}_{2}$ 
nanotubes)/ $\mathrm{M}_{\mathrm{Ti}-0}$ ( $\mathrm{Ti}$ mesh substrate)) [17-19]. Meanwhile, the 3D $\mathrm{TiO}_{2}$ nanotube arrays allow $\mathrm{Li}^{+}$to more easily access the $\mathrm{TiO}_{2}$ surface from the electrolyte [20, 21]. Some reports have shown real benefits from the 3D electrode design, such as in LIBs using Sn/graphene in a 3D multilayer structure and 3D ordered porous Sn-Ni alloy as anode to improve the specific area capacity, conductivity, and cycling stability [22, 23]. The benefits for lithium ion batteries associated with 3D nanotube arrays of $\mathrm{TiO}_{2}$ grown on $\mathrm{Ti}$ mesh, however, have not been studied to date.

Here, $\mathrm{TiO}_{2} / \mathrm{Ti}$ mesh as a new type of anode material was prepared by the electrochemical anodization method. $\mathrm{TiO}_{2} / \mathrm{Ti}$ mesh can be applied directly as an electrode material in a test cell without the need for a current collector or binder. 3D $\mathrm{TiO}_{2}$ radial nanotube arrays with different lengths were grown on Ti mesh by controlling the anodization time. The special architecture of the 3D nanotube arrays with large surface area can provide effective contact between the active materials and the electrolyte, and shorten the lithium diffusion length. Moreover, the thin Ti wires at the centre of the nanotubes can maintain good conductivity. In this work, we tested the properties of $\mathrm{TiO}_{2} / \mathrm{Ti}$ mesh electrodes with different anodization processing times. When the anodization processing time was $600 \mathrm{~min}$, the investigated $\mathrm{TiO}_{2} / \mathrm{Ti}$ mesh electrode possessed both high electrochemical performance and good mechanical behaviour.

\section{Experimental}

3D $\mathrm{TiO}_{2}$ nanotube arrays on $\mathrm{Ti}$ mesh were prepared following our previous method [24]. A polished piece of Ti mesh $\left(30 \times 55 \mathrm{~mm}^{2}, 100\right.$ mesh, $0.1 \mathrm{~mm}$ thick, purity $\left.99.5 \mathrm{wt} \%\right)$ was anodized in organic electrolyte consisting of ammonium fluoride $\left(\mathrm{NH}_{4} \mathrm{~F}, 0.25 \mathrm{wt} \%\right)$ and ethylene glycol (EG; $\left(\mathrm{HOCH}_{2}\right)_{2}, 98$ vol\%; $\mathrm{H}_{2} \mathrm{O}, 2$ vol\%). The potential was supplied by a

laboratory DC power supply (TPR-6405, LWDQGS). The nanotube length could be 
increased by increasing the anodization time of the Ti mesh at $20 \mathrm{~V}$ in organic electrolyte. The as-prepared $\mathrm{TiO}_{2} / \mathrm{Ti}$ meshes were annealed at $500{ }^{\circ} \mathrm{C}$ under ambient air for $3 \mathrm{~h}$ to induce $\mathrm{TiO}_{2}$ crystallization. The $\mathrm{TiO}_{2} / \mathrm{Ti}$ meshes were analysed by X-ray diffraction (XRD; GBC MMA) with $\mathrm{Cu} \mathrm{K} \alpha$ radiation, as well as by field emission scanning electron microscopy (FESEM; JEOL 7500).

The $\mathrm{TiO}_{2} / \mathrm{Ti}$ mesh electrodes were cut to $1 \times 1 \mathrm{~cm}^{2}$ in size and then dried at $80{ }^{\circ} \mathrm{C}$ in a vacuum oven for 24 h. CR 2032 coin-type cells were assembled in an Ar-filled glove box (Mbraun, Unilab, Germany), using lithium metal foil as the counter electrode. The electrolyte was $1 \mathrm{M} \mathrm{LiPF}_{6}$ in a mixture of ethylene carbonate (EC) and diethyl carbonate (DEC) (1:1 by volume, provided by MERCK KGaA, Germany). The cells were galvanostatically charged and discharged in the range of 3.0-1.0 $\mathrm{V}$ at different current densities using a computercontrolled charger system manufactured by Land Battery Testers. A Biologic VMP-3 electrochemical workstation was used to perform cyclic voltammetry (CV; scanning rate 0.1 $\left.\mathrm{mV} \mathrm{s}^{-1}\right)$.

\section{Results and discussion}

Fig. 1 shows the XRD patterns of the $3 \mathrm{D} \mathrm{TiO}_{2}$ nanotube arrays on $\mathrm{Ti}$ mesh prepared by anodization in organic electrolyte over periods ranging from $60 \mathrm{~min}$ to $720 \mathrm{~min}$, with the samples designated as $\mathrm{TiO}_{2} / \mathrm{Ti}-t$ mesh $(t=0,60,180,420,600,720 \mathrm{~min}$; the different anodization time intervals were used to obtain more comprehensive results and are also mentioned in our previous report) [24]. After annealing at $500{ }^{\circ} \mathrm{C}$, the $\mathrm{TiO}_{2}$ nanotubes on $\mathrm{Ti}$ mesh (JCPDS 44-1294) are mainly anatase phase (JCPDS 21-1272). Some weak peaks related to the rutile phase (JCPDS 44-1276) appear in the XRD patterns of the $\mathrm{TiO}_{2} / \mathrm{Ti}-t$ mesh samples, but the nanotubes are mostly still composed of anatase phase [16]. Varghese et al. reported that rutile phase mainly existed in the barrier layer underlying the $\mathrm{TiO}_{2}$ nanotube 
arrays [25]. With increasing anodization processing time, the intensity of the rutile phase peaks decreases, while the intensity of the anatase phase peaks increases because the weight percentage of $\mathrm{TiO}_{2}$ nanotubes is increased.

FESEM images of the anodic $\mathrm{TiO}_{2}$ nanotubes on the Ti mesh substrates are presented in Fig. 2. Fig. 2 shows that the diameter of the $\mathrm{TiO}_{2} / \mathrm{Ti}$ wire increases with prolonged anodization processing time. When the anodization processing time is $60 \mathrm{~min}$, the morphology of the $\mathrm{TiO}_{2} / \mathrm{Ti}-60 \mathrm{~min}$ mesh has only slightly changed compared with the $\mathrm{Ti}$ mesh, because the additional diameter of the $\mathrm{TiO}_{2} / \mathrm{Ti}$ wire is only around $10 \mu \mathrm{m}$, while the diameter of the bare Ti wire is $90.2 \mu \mathrm{m}$ [Fig. 2(a, b)]. With increasing anodization processing time, the $\mathrm{TiO}_{2}$ nanotube arrays are interspaced with fissures at irregular intervals [Fig. 2(c-f)]. This can be attributed to van der Waals attraction and capillary forces during drying [16-18]. Meanwhile, we can see from the Fig 2(b-f) insets that the $\mathrm{TiO}_{2}$ nanotube arrays and the $\mathrm{Ti}$ wire substrates have been separated at their interfaces due to the stress when the $\mathrm{TiO}_{2} / \mathrm{Ti}$ mesh was cut down during the FESEM characterization. From Fig. 2, we can measure the diameters of the $\mathrm{Ti}$ and $\mathrm{TiO}_{2} / \mathrm{Ti}$ wires and the length of the $\mathrm{TiO}_{2}$ nanotubes. Fig. 3(a) shows the geometric parameters of the $\mathrm{TiO}_{2} / \mathrm{Ti}$ mesh obtained by anodization in organic electrolyte. The diameters of the $\mathrm{Ti}$ and $\mathrm{TiO}_{2} / \mathrm{Ti}$ wires and the length of the $\mathrm{TiO}_{2}$ nanotubes have a linear relationship with the anodization processing time [Fig. 3(b)]. The Ti mesh did not react with the organic electrolyte when $t$ was 0 min, so the intercepts for the $\mathrm{TiO}_{2} / \mathrm{Ti}$ wire diameter and the $\mathrm{Ti}$ wire diameter have the same value $(90.2 \mu \mathrm{m}$, the diameter of the Ti wire before anodization), and the intercept for the $\mathrm{TiO}_{2}$ nanotube length is 0 . The linear fit results can be written as the following equations

$D=k_{1} \times t+B$

$d=-k_{2} \times t+B$ 
$h=k_{3} \times t$

where $D$ is the diameter of the $\mathrm{TiO}_{2} / \mathrm{Ti}$ wire $(\mu \mathrm{m}), d$ is the diameter of the Ti wire $(\mu \mathrm{m}), h$ is the length of the $\mathrm{TiO}_{2}$ nanotubes $(\mu \mathrm{m}), t$ is the anodization processing time $(\mathrm{min}), k_{1}, k_{2}, k_{3}$ is the growth rate with processing time of the $\mathrm{TiO}_{2} / \mathrm{Ti}$ wire diameter, the $\mathrm{Ti}$ wire diameter, and the $\mathrm{TiO}_{2}$ nanotube length, respectively, and $B$ is the $\mathrm{TiO}_{2} / \mathrm{Ti}$ wire and $\mathrm{Ti}$ wire diameter intercept $(B=90.2 \mu \mathrm{m})$. From the linear fit results, the absolute values of the slopes have similar values $\left(|K| \approx 0.08 ; k_{1}=0.081( \pm 0.007), k_{2}=-0.079( \pm 0.004), k_{3}=0.080( \pm 0.005)\right)$. Therefore, the relationship between $D$ and $d$ can be written as in the following equation

$$
D=|K| \times t+B
$$

For the Ti mesh used here, the distance between two adjacent Ti wires $\left(a_{\mathrm{Ti}-\mathrm{Ti}}\right)$ is $257.1 \mu \mathrm{m}$ for $\mathrm{Ti}$ mesh. There will be no void regions between two adjacent $\mathrm{TiO}_{2} / \mathrm{Ti}$ wires in the $\mathrm{TiO}_{2} / \mathrm{Ti}$ mesh when $D$ approaches $257.1 \mu \mathrm{m}$. That is to say, the void regions in the Ti mesh will be fully filled with $\mathrm{TiO}_{2}$ nanotube arrays, so that the $\mathrm{TiO}_{2} / \mathrm{Ti}$ mesh shows the highest specific surface area. Meanwhile, the electrolyte can penetrate to the entire surface of the $\mathrm{TiO}_{2}$ nanotubes due to the nanotube arrays that are radially grown on the Ti wires [Fig. 3(a, c-e)]. For the $\mathrm{TiO}_{2} / \mathrm{Ti}$ mesh samples, however, the $\mathrm{TiO}_{2}$ nanotube arrays are easily detached from the Ti mesh when $t$ is $720 \mathrm{~min}$, because the length of the $\mathrm{TiO}_{2}$ nanotubes $\left(h_{\mathrm{TiO} 2}=61.4 \mu \mathrm{m}\right)$ is around two times the diameter of the $\mathrm{Ti}$ wire $\left(d_{T i}=30.1 \mu \mathrm{m}\right.$; Fig. 2(f)). The $\mathrm{TiO}_{2} / \mathrm{Ti}-720 \mathrm{~min}$ mesh electrode shows poor mechanical behavior. Fig. 2(e) shows that the $\mathrm{TiO}_{2} / \mathrm{Ti}$ mesh with 600 min anodization processing has been uniformly covered with $\mathrm{TiO}_{2}$ nanotubes, and the ratio of $h_{T i O 2} / d_{T i}$ is $1.2\left(h_{T i O 2}=50.5 \mu \mathrm{m}, d_{T i}=43.6 \mu \mathrm{m}\right)$. The Ti conversion rate can be calculated from the masses of the Ti mesh and the $\mathrm{TiO}_{2} / \mathrm{Ti}-600 \mathrm{~min}$ mesh for $1 \mathrm{~cm}^{2}$ electrode area (18.1 mg and $11.56 \mathrm{mg}$, respectively). The Ti conversion rate is $22 \mathrm{wt} \%$, much higher than that previously reported (2 wt\%) [16]. Therefore, the $\mathrm{TiO}_{2} / \mathrm{Ti}-600 \mathrm{~min}$ mesh electrode is 
the most promising electrode, as it has high surface area, good mechanical behavior, and a high Ti conversion rate. Furthermore, by controlling the distance between two adjacent $\mathrm{Ti}$ wires and controlling the anodization processing time, we can obtain higher surface area and better mechanical behavior in $\mathrm{TiO}_{2} / \mathrm{Ti}$ mesh electrode for lithium-ion batteries.

In order to compare $\mathrm{TiO}_{2} / \mathrm{Ti}$ mesh electrode prepared over a short time (60 min) and a longer time (600 min), we conducted FESEM using high magnification. FESEM images of anodic $\mathrm{TiO}_{2}$ nanotubes on the $\mathrm{Ti}$ mesh substrates are presented in Fig. 2(b, e), and high magnification FESEM images are presented in Fig. 4(a, b). After the 60 min anodization process, the mesh retained sufficient void regions, and the $\mathrm{TiO}_{2}$ nanotubes grew perpendicularly to the surface of the Ti wire and covered the entire wire uniformly [Fig. 2(b)]. The Ti wires act as the current collector during LIB testing. The length and inner diameter of the $\mathrm{TiO}_{2}$ nanotubes are $\sim 4.9 \mu \mathrm{m}$ and $\sim 100 \mathrm{~nm}$, respectively [Fig. 2(b) and Fig. 4(a)]. The length and inner diameter of the $\mathrm{TiO}_{2}$ nanotubes are $\sim 50.5 \mu \mathrm{m}$ and $\sim 100 \mathrm{~nm}$, respectively, when the anodization processing time is $600 \mathrm{~min}$ [Fig. 2(e) and Fig. 4(b)].

The $\mathrm{TiO}_{2} / \mathrm{Ti}-60 \mathrm{~min}$ mesh electrode and $\mathrm{TiO}_{2} / \mathrm{Ti}-600 \mathrm{~min}$ mesh electrode were selected to test their performance in LIBs. Fig. 5(a, b) shows cyclic voltammograms of $\mathrm{TiO}_{2} / \mathrm{Ti}$ mesh for the first five cycles at the scan rate of $0.1 \mathrm{mV} \mathrm{s}^{-1}$. In the first cycle, the $\mathrm{TiO}_{2} / \mathrm{Ti}-60 \mathrm{~min}$ mesh electrode presents a pair of cathodic/anodic peaks centred at $1.65 \mathrm{~V}$ and $2.10 \mathrm{~V}$ (vs. $\mathrm{Li} / \mathrm{Li}^{+}$), corresponding to lithium insertion/extraction into/from the anatase $\mathrm{TiO}_{2}$ lattice, respectively, while the $\mathrm{TiO}_{2} / \mathrm{Ti}-600$ min mesh electrode's cathodic/anodic peaks are centred at 1.55 $\mathrm{V}$ and $2.15 \mathrm{~V}$ (vs. $\mathrm{Li} / \mathrm{Li}^{+}$). In the following cycles, however, both the $\mathrm{TiO}_{2} / \mathrm{Ti}-60 \mathrm{~min}$ mesh and the $\mathrm{TiO}_{2} / \mathrm{Ti}-600$ min mesh electrodes show a single pair of cathodic/anodic peaks at about $1.70 \mathrm{~V}$ and $2.05 \mathrm{~V}$ (vs. $\mathrm{Li} / \mathrm{Li}^{+}$), consistent with a two-phase redox reaction of $x \mathrm{Li}^{+}+x \mathrm{e}^{-}$ $+\mathrm{TiO}_{2} \leftrightarrow \mathrm{Li}_{x} \mathrm{TiO}_{2}(x \approx 0.5)[4,26]$. A similar observation has been previously reported, and it has been ascribed to an activation effect during the initial cycling of the $\mathrm{TiO}_{2}$ nanotubes [27]. 
It should be noted that there is a pair of broad and low cathodic/anodic peaks that appear around $1.4 \mathrm{~V}$ and $1.6 \mathrm{~V}$ (vs. $\mathrm{Li} / \mathrm{Li}^{+}$) [Fig. 5(a, b)]. These peaks correspond to lithium insertion/extraction into/from the rutile $\mathrm{TiO}_{2}$ lattice, respectively [1]. These cathodic and anodic peaks are in accordance with the plateaus in the discharge/charge curves. Fig. 5(c, d) displays typical discharge/charge curves for the $\mathrm{TiO}_{2} / \mathrm{Ti}-60 \mathrm{~min}$ mesh and $\mathrm{TiO}_{2} / \mathrm{Ti}-600 \mathrm{~min}$ mesh electrodes at different current densities from 50 to $1000 \mu \mathrm{A} \mathrm{cm}{ }^{-2}$. The $\mathrm{TiO}_{2} / \mathrm{Ti}-60 \mathrm{~min}$ mesh electrode starts to show sloping discharge curves from $250 \mu \mathrm{A} \mathrm{cm}{ }^{-2}$, whereas the $\mathrm{TiO}_{2} / \mathrm{Ti}-600 \mathrm{~min}$ mesh electrode still shows a flat plateau, even at $500 \mu \mathrm{A} \mathrm{cm}{ }^{-2}$. Those results suggest that the kinetic properties of the $\mathrm{TiO}_{2} / \mathrm{Ti}$ mesh electrode have remained stable with increasing length of the $\mathrm{TiO}_{2}$ nanotubes.

Fig. 5(e) shows the cycling performances of the $\mathrm{TiO}_{2} / \mathrm{Ti}-60 \mathrm{~min}$ mesh and $\mathrm{TiO}_{2} / \mathrm{Ti}$ $600 \mathrm{~min}$ mesh electrodes at $50 \mu \mathrm{A} \mathrm{cm}{ }^{-2}$. The $\mathrm{TiO}_{2} / \mathrm{Ti}-60 \mathrm{~min}$ mesh electrode shows an initial discharge capacity of $720.9 \mu \mathrm{A} \mathrm{h} \mathrm{cm}^{-2}$. After the second cycle, the capacity retention remains stable at around $600 \mu \mathrm{A} \mathrm{h} \mathrm{cm} \mathrm{cm}^{-2}$. After 30 cycles, however, the discharge capacity continuously decreases to $388.9 \mu \mathrm{A} \mathrm{h} \mathrm{cm}^{-2}$. The capacity retention after 100 cycles is around $54 \%$ of the initial discharge capacity. In comparison, the $\mathrm{TiO}_{2} / \mathrm{Ti}-600 \mathrm{~min}$ mesh electrode shows great enhancement of the capacity retention. The $\mathrm{TiO}_{2} / \mathrm{Ti}-600 \mathrm{~min}$ mesh electrode shows an initial discharge capacity of $2249.9 \mu \mathrm{A} \mathrm{h} \mathrm{cm}^{-2}$, and after 100 cycles, it was measured to be $1745.5 \mu \mathrm{A} \mathrm{h} \mathrm{cm}{ }^{-2}$, which is around $78 \%$ of the initial discharge capacity. For comparing specific capacity with other reported nanostructured $\mathrm{TiO}_{2}$ anodes, the specific capacity of the $\mathrm{TiO}_{2} / \mathrm{Ti}-600 \mathrm{~min}$ mesh $\left(1 \mathrm{~cm}^{-2}\right)$ based on its mass $(11.56 \mathrm{mg})$ was calculated. The initial discharge capacity and the discharge capacity after 100 cycles were $195.3 \mathrm{mAh} \mathrm{g}^{-1}$ and $151.5 \mathrm{mAh} \mathrm{g}^{-1}$, respectively, and the discharge current density was $4.3 \mathrm{~mA} \mathrm{~g}^{-1}$, similar to other reports in the literature (where the capacity is between $100 \mathrm{mAh} \mathrm{g}^{-1}$ and $170 \mathrm{mAh} \mathrm{g}^{-1}$ after 100 cycles at $20 \mathrm{~mA} \mathrm{~g}^{-1}$ [1, 2, 4, 12, 28]). Fig. 5(f) shows the specific capacity retention 
rate as a function of current density for lithium cells containing the $\mathrm{TiO}_{2} / \mathrm{Ti}-60 \mathrm{~min}$ mesh and $\mathrm{TiO}_{2} / \mathrm{Ti}-600 \mathrm{~min}$ mesh electrodes. As shown in Fig. 5(f), the specific capacity retention rate of the $\mathrm{TiO}_{2} / \mathrm{Ti}-600 \mathrm{~min}$ mesh electrode decreases much more slowly with increasing discharge rate than that of the $\mathrm{TiO}_{2} / \mathrm{Ti}-60$ min mesh electrode. Although the $3 \mathrm{D} \mathrm{TiO}_{2}$ nanotube arrays on the $\mathrm{Ti}$ mesh are as long as $50.5 \mu \mathrm{m}$, the $\mathrm{TiO}_{2} / \mathrm{Ti}$ mesh cell always maintains its high area capacity, stable cycling performance, and high rate capability. The cycling stability and rate performance of the $\mathrm{TiO}_{2} / \mathrm{Ti}-600 \mathrm{~min}$ mesh electrode could be attributed to the particular geometry, in which the $\mathrm{TiO}_{2}$ nanotubes extend radially in a 3D array on a grid of $\mathrm{Ti}$ wires, allowing $\mathrm{e}^{-}$and $\mathrm{Li}^{+}$to more easily access the $\mathrm{TiO}_{2}$ surface.

To further understand the kinetic processes of the electrode reactions, electrochemical impedance spectroscopy (EIS) measurements were performed on the $\mathrm{TiO}_{2} / \mathrm{Ti}-60 \mathrm{~min}$ and $\mathrm{TiO}_{2} / \mathrm{Ti}-600 \mathrm{~min}$ mesh electrodes. Fig. 6(a) shows the Nyquist plots of the electrodes at a discharge potential of $1.7 \mathrm{~V}$ vs. $\mathrm{Li} / \mathrm{Li}^{+}$at $25{ }^{\circ} \mathrm{C}$ after cycling over 10 cycles. All the impedance curves show two partly overlapping semicircles in the high to medium frequency region, which could be assigned to the film resistance $\left(R_{f}\right)$ of the solid electrolyte interphase (SEI) and the charge transfer resistance $\left(R_{c t}\right)$, respectively. A line inclined at approximately $45^{\circ}$ reflects the Warburg impedance (W), which is associated with the lithium-ion diffusion in the $\mathrm{TiO}_{2}$ nanotubes. The high-frequency intercept of the semicircle reflects the uncompensated resistance $\left(R_{l}\right)$, which includes the particle-particle contact resistance, the electrolyte resistance, and the resistance between the $\mathrm{TiO}_{2}$ nanotube arrays and the $\mathrm{Ti}$ wire [29, 30]. The $R_{f}, R_{c t}$, and $R_{l}$ for the $\mathrm{TiO}_{2} / \mathrm{Ti}-60 \mathrm{~min}$ and $\mathrm{TiO}_{2} / \mathrm{Ti}-600 \mathrm{~min}$ mesh electrodes were obtained using the equivalent circuit shown in the inset of Fig. 6(a) (calculated by Zview). The $R_{l}$ of the $\mathrm{TiO}_{2} / \mathrm{Ti}-60 \mathrm{~min}$ mesh electrode $(7.8 \Omega)$ is similar to that of the $\mathrm{TiO}_{2} / \mathrm{Ti}-600 \mathrm{~min}$ mesh electrode $(8.3 \Omega)$, indicating that the interface between the nanotube arrays and the $\mathrm{Ti}$ wire is stable and adhesive. On comparing the diameters of the semicircles, the $R_{f}$ of the 
$\mathrm{TiO}_{2} / \mathrm{Ti}-60 \mathrm{~min}$ mesh electrode is similar to that of the $\mathrm{TiO}_{2} / \mathrm{Ti}-600 \mathrm{~min}$ mesh electrode $(15.7$ $\Omega$ and $24.2 \Omega$, respectively), due to the particular geometry, which hinders SEI formation. The thickness of the $\mathrm{TiO}_{2}$ nanotubes is about $20 \mathrm{~nm}$, so the $R_{c t}$ values of the $\mathrm{TiO}_{2} / \mathrm{Ti}-60 \mathrm{~min}$ mesh and the $\mathrm{TiO}_{2} / \mathrm{Ti}-600$ min mesh electrodes are very small (3.1 $\Omega$ and $6.8 \Omega$, respectively). The EIS can also be used to calculate the lithium diffusion coefficient using the following equation [31-33]

$D=R^{2} T^{2} / 2 A^{2} n^{4} F^{4} C^{2} \sigma^{2}$

where $R$ is the gas constant, $T$ is the absolute temperature, $A$ is the surface area of the cathode $\left(1 \mathrm{~cm}^{2}\right), n$ is the number of electrons transferred in the half-reaction for the redox couple, which is equal to $0.5, F$ is the Faraday constant, $C$ is the concentration of $\mathrm{Li}$ ions in the solid material $\left(1.39 \times 10^{-3} \mathrm{~mol} \mathrm{~cm}{ }^{-3}\right), D$ is the diffusion coefficient $\left(\mathrm{cm}^{2} \mathrm{~s}^{-1}\right)$, and $\sigma$ is the Warburg factor, which is relative to $Z_{\mathrm{re}}$ [34]. $\sigma$ can be obtained from the slope of the lines in Fig. 6(b).

$Z_{\mathrm{re}}=R_{l}+R_{c t}+\sigma \omega^{-1 / 2}$

The lithium diffusion coefficients are calculated to be $6.0 \times 10^{-9} \mathrm{~cm}^{2} \mathrm{~s}^{-1}$ and $3.3 \times 10^{-9} \mathrm{~cm}^{2} \mathrm{~s}^{-1}$ for the $\mathrm{TiO}_{2} / \mathrm{Ti}-60 \mathrm{~min}$ mesh and the $\mathrm{TiO}_{2} / \mathrm{Ti}-600$ min mesh, respectively, at $25{ }^{\circ} \mathrm{C}$. This indicates that the $\mathrm{TiO}_{2} / \mathrm{Ti}-600 \mathrm{~min}$ mesh electrode can maintain good electrochemical kinetics.

A morphological study of the electrodes before cycling and after 100 cycles was also conducted. The $\mathrm{TiO}_{2} / \mathrm{Ti}-60 \mathrm{~min}$ mesh electrode before cycling shows a smooth surface [Fig. 2(b) and Fig. 4(a)], while the $\mathrm{TiO}_{2} / \mathrm{Ti}-600 \mathrm{~min}$ mesh electrode shows some $\mathrm{TiO}_{2}$ nanotube arrays interspaced with fissures at irregular intervals on the Ti wire surface [Fig. 2(e) and Fig. 4(b)]. Compared with before cycling, the electrodes after cycling show similar morphology. Fig. 7(a) is a FESEM image showing the surface of the $\mathrm{TiO}_{2} / \mathrm{Ti}-60 \mathrm{~min}$ mesh after 100 cycles. 
No changes can be observed on the surface of the electrode. The high magnification image of the cross-section shows that some electrolyte particles have not been washed off, and the surface of the $\mathrm{TiO}_{2}$ nanotube is very smooth due to the particular geometry [Fig. 7(b, c)]. The $\mathrm{TiO}_{2} / \mathrm{Ti}-600 \mathrm{~min}$ mesh electrode surface shows the same morphology as before cycling, and the SEI layer can be seen on the inside and outside of the $\mathrm{TiO}_{2}$ nanotubes [Fig. 7(e, f)] [35, 36]. This excellent stability of the electrode should be attributed to the particular architecture. Traditional nanostructured electrodes are easy to damage after long cycling, however, for the $\mathrm{TiO}_{2} / \mathrm{Ti}$ mesh electrodes used here, the Ti wires act as the current collector and as a frame to protect the $\mathrm{TiO}_{2}$ nanotube arrays from being damaged and detached [37, 38]. As can be seen from the cross-section of the $\mathrm{TiO}_{2} / \mathrm{Ti}-600$ min mesh electrode, the $3 \mathrm{D} \mathrm{TiO}_{2}$ nanotube arrays efficiently prevent the SEI layer from increasing, even though the length of the $\mathrm{TiO}_{2}$ nanotube is $50.5 \mu \mathrm{m}$ [Fig. 7(e)].

\section{Conclusions}

In summary, a new type of electrode consisting of long $3 \mathrm{D} \mathrm{TiO}_{2}$ nanotube arrays on $\mathrm{Ti}$ mesh was manufactured using the electrochemical anodization method. The $\mathrm{TiO}_{2}$ nanotubes extend radially in a 3D array on a grid of Ti wires. The Ti wires acted as the current collector during LIB testing. The Ti conversion rate was increased to around $22 \mathrm{wt} \%$. This electrode, which does not need a current collector or binder, has flat potential plateaus, high specific area capacity, and high rate capability, on the same level as reported for nanostructured $\mathrm{TiO}_{2}$ anode. Therefore, this novel 3D structured $\mathrm{TiO}_{2} / \mathrm{Ti}$ mesh is a very promising anode material for LIBs.

\section{Acknowledgements:}

Financial support was provided by an Australian Research Council (ARC) Discovery Project (DP100103909). Zhijia Zhang is grateful to the China Scholarship Council (CSC) for 
scholarship support. Many thanks are owed to Dr. Tania Silver for critical reading of the manuscript.

\section{References}

[1] D. Wang, D. Choi, J. Li, Z. Yang, Z. Nie, R. Kou, D. Hu, C. Wang, L. Saraf, J. Zhang, I. Aksay, J. Liu, Self-assembled $\mathrm{TiO}_{2}$-graphene hybrid nanostructures for enhanced $\mathrm{Li}$-ion insertion, ACS Nano 3 (2009) 907.

[2] J. Wang, Y. Bai, M. Wu, J. Yin, W.F. Zhang, Preparation and electrochemical properties of $\mathrm{TiO}_{2}$ hollow spheres as an anode material for lithium-ion batteries, J. Power Sources 191 (2009) 614.

[3] D. Nan, J.G. Wang, Z.H. Huang, L. Wang, W. Shen, F. Kang, Highly porous carbon nanofibers from electrospun polyimide/ $\mathrm{SiO}_{2}$ hybrids as an improved anode for lithium-ion batteries, Electrochem. Commun. 34 (2013) 52.

[4] Y. Wang, M. Wu, W.F. Zhang, Preparation and electrochemical characterization of $\mathrm{TiO}_{2}$ nanowires as an electrode material for lithium-ion batteries, Electrochim. Acta 53 (2008) 7863.

[5] G.F. Ortiz, I. Hanzu, P. Knauth, P. Lavela, J.L. Tirado, T. Djenizian, $\mathrm{TiO}_{2}$ nanotubes manufactured by anodization of $\mathrm{Ti}$ thin films for on-chip Li-ion 2D microbatteries, Electrochim. Acta 54 (2009) 4262.

[6] J.S. Kim, K.S. Kim, W. Cho, W.H. Shin, R. Kanno, J.W. Choi, A Truncated manganese spinel cathode for excellent power and lifetime in lithium-ion batteries, Nanao Lett. 12 (2012) 6358.

[7] Z. Zhou, D. Zhao, X.W. Lou, $\mathrm{LiNi}_{0.5} \mathrm{Mn}_{1.5} \mathrm{O}_{4}$ hollow structures as high-performance 
cathodes for lithium-ion batteries, Angew. Chem., Int. Ed. 124 (2012) 243.

[8] J. Yang, X. Han, X. Zhang, F. Cheng, J. Chen, Spinel $\mathrm{LiNi}_{0.5} \mathrm{Mn}_{1.5} \mathrm{O}_{4}$ cathode for rechargeable lithium-ion batteries: Nano vs micro, ordered phase (P4332) vs disordered phase (Fd-3m), Nano Res. 6(9) (2013) 679.

[9] Y. Shi, J.Z. Wang, S.L. Chou, D. Wexler, H.J. Li, K. Ozawa, H.K. Liu, Y.P. Wu, Hollow structured $\mathrm{Li}_{3} \mathrm{VO}_{4}$ wrapped with graphene nanosheets in situ prepared by a one-pot templatefree method as an anode for lithium-ion batteries, Nano Lett. 13 (2013) 4715.

[10] P.M. Dziewonski, M. Grzeszczuk, Towards $\mathrm{TiO}_{2}$-conducting polymer hybrid materials for lithium ion batteries, Electrochim. Acta 55 (2010) 3336.

[11] F. Wu, X. Li, Z. Wang, H. Guo, L. Wu, X. Xiong, X. Wang, A novel method to synthesize anatase $\mathrm{TiO}_{2}$ nanowires as an anode material for lithium-ion batteries, J. Alloys Compd. 509 (2011) 3711.

[12] Z. Sun, J.H. Kim, Y. Zhao, F. Bijarbooneh, V. Malgras, Y. Lee, Y.M. Kang, S.X. Dou, Rational design of 3D dendritic $\mathrm{TiO}_{2}$ nanostructures with favorable architectures, J. Am. Chem. Soc. 133 (2011) 19314.

[13] Z. Liu, V. Subramania, M. Misra, Vertically oriented $\mathrm{TiO}_{2}$ nanotube arrays grown on $\mathrm{Ti}$ meshes for flexible dye-sensitized solar cells, J. Phys. Chem. C 113(31) (2009) 14208.

[14] Y.Q. Liang, Z.D. Cui, S.L. Zhu, Y. Liu, X.J. Yang, Silver nanoparticles supported on $\mathrm{TiO}_{2}$ nanotubes as active catalysts for ethanol oxidation, J. Catal. 278 (2011) 276.

[15] Y. Ohsaki, N. Masaki, T. Kitamura, Y. Wada, T. Okamoto, T. Sekino, K. Niihara, S. Yanagida, Dye-sensitized $\mathrm{TiO}_{2}$ nanotube solar cells: Fabrication and electronic characterization, Phys. Chem. Chem. Phys. 7 (2005) 4157. 
[16] J. Liao, S. Lin, L. Zhang, N. Pan, X. Cao, J. Li, Photocatalytic degradation of methyl orange using a $\mathrm{TiO}_{2} / \mathrm{Ti}$ mesh electrode with 3D nanotube arrays, ACS Appl. Mater. Interfaces $4(2012) 171$.

[17] W. He, J. Qiu, F. Zhuge, X. Li, J.H. Lee, Y.D. Kim, H.K. Kim, Y.H. Hwang, Advantages of using Ti-mesh type electrodes for flexible dye-sensitized solar cells, Nanotechnology 23 (2012) 225602.

[18] Z. Liu, Q. Zhang, T. Zhao, J. Zhai, L. Jiang, 3-D vertical arrays of $\mathrm{TiO}_{2}$ nanotubes on $\mathrm{Ti}$ meshes: Efficient photoanodes for water photoelectrolysis, J. Mater. Chem. 21 (2011) 10354. [19] Y.B. Xie, X.Z. Li, Interactive oxidation of photoelectrocatalysis and electro-Fenton for azo dye degradation using $\mathrm{TiO}_{2}$ - $\mathrm{Ti}$ mesh and reticulated vitreous carbon electrodes, Mater. Chem. Phys. 95 (2006) 39.

[20] Z. Wei, Z. Liu, R. Jiang, C. Bian, T. Huang, A. Yu, $\mathrm{TiO}_{2}$ nanotube array film prepared by anodization as anode material for lithium ion batteries, J. Solid State Electrochem. 14 (2010) 1045.

[21] G.K. Mor, K. Shankar, M. Paulose, O.K. Varghese, C.A. Grimes, Use of highly-ordered $\mathrm{TiO}_{2}$ nanotube arrays in dye-sensitized solar cells, Nano Lett. 6(2) (2006) 215.

[22] G. Wang, B. Wang, X. Wang, J. Park, S. Dou, H. Ahn, K. Kim, Sn/graphene nanocomposite with 3D architecture for enhanced reversible lithium storage in lithium ion batteries, J. Mater. Chem. 19 (2009) 8378.

[23] F.S. Ke, L. Huang, H.H. Jiang, H.B. Wei, F.Z. Yang, S.G. Sun, Fabrication and properties of three-dimensional macroporous Sn-Ni alloy electrodes of high preferential (1 1 0) orientation for lithium ion batteries, Electrochem. Commun. 9 (2007) 228.

[24] Q.Y. Zeng, M. Xi, W Xu, X.J. Li, Preparation of titanium dioxide nanotube arrays on titanium mesh by anodization in $\left(\mathrm{NH}_{4}\right)_{2} \mathrm{SO}_{4} / \mathrm{NH}_{4} \mathrm{~F}$ electrolyte, Mater. Corros. 64(11) (2013) 1001. 
[25] O.K. Varghese, D. Gong, M. Paulose, C.A. Grimes, E.C. Dickey, Crystallization and high-temperature structural stability of titanium oxide nanotube arrays, J. Mater. Res. 18(1) 2003156.

[26] F. Bonino, L. Busani, M. Lazzari, M. Manstretta, B. Rivolta, Anatase as a cathode material in lithium-organic electrolyte rechargeable batteries, J. Power Sources 6 (1981) 261.

[27] H. Zhang, G.R. Li, L.P. An, T.Y. Yan, X.P. Gao, H.Y. Zhu, Electrochemical lithium storage of titanate and titania nanotubes and nanorods, J. Phys. Chem. C 111(16) (2007) 6143.

[28] C. Li, G.R. Li, Y.Y. Dou, X.P. Gao, Mesoporous polyaniline or polypyrrole/anatase $\mathrm{TiO}_{2}$ nanocomposite as anode materials for lithium-ion batteries, Electrochim. Acta 55 (2010) 4567.

[29] B.L. He, B. Dong, H.L. Li, Preparation and electrochemical properties of Ag-modified $\mathrm{TiO}_{2}$ nanotube anode material for lithium-ion battery, Electrochem. Commun. 9 (2007) 425.

[30] A.V. Murugan, T. Muraliganth, A. Manthiram, One-pot microwave-hydrothermal synthesis and characterization of carbon-coated $\mathrm{LiMPO}_{4}(\mathrm{M}=\mathrm{Mn}, \mathrm{Fe}$, and Co) cathodes, J. Electrochem. Soc. 156 (2009) A79.

[31] Z.J. Zhang, J.Z. Wang, S.L. Chou, H.K. Liu, K. Ozawa, H.J. Li, Polypyrrole-coated $\alpha-$ $\mathrm{LiFeO}_{2}$ nanocomposite with enhanced electrochemical properties for lithium-ion batteries, Electrochim. Acta 108 (2013) 820.

[32] S.L. Chou, J.Z. Wang, H.K. Liu, S.X. Dou, Rapid synthesis of $\mathrm{Li}_{4} \mathrm{Ti}_{5} \mathrm{O}_{12}$ microspheres as anode materials and its binder effect for lithium-ion battery, J. Phys. Chem. C 115 (2011) 16220. 
[33] N. Takami, A. Satoh, M. Hara, T. Ohsaki, Structural and kinetic characterization of lithium intercalation into carbon anodes for secondary lithium batteries, J. Electrochem. Soc. 142 (1995) 371.

[34] A.J. Bard, L.R. Faulkner, Electrochemical methods: Fundamentals and applications (2 ${ }^{\text {nd }}$ Edition), Wiley, New York, 2001.

[35] S.L. Chou, X.W. Gao, J.Z. Wang, D. Wexler, Z.X. Wang, L.Q. Chen, H.K. Liu, Tin/polypyrrole composite anode using sodium carboxymethyl cellulose binder for lithiumion batteries , Dalton Trans. 40 (2011) 12801.

[36] D. Deng, M.G. Kim, J.Y. Lee, J. Cho, Green energy storage materials: Nanostructured $\mathrm{TiO}_{2}$ and Sn-based anodes for lithium-ion batteries, Energy Environ. Sci. 2 (2009) 818.

[37] H. Wu, G. Chan, J.W. Choi, I. Ryu, Y. Yao, M.T. McDowell, S.W. Lee, A. Jackson, Y. Yang, L. Hu, Y Cui, Stable cycling of double-walled silicon nanotube battery anodes through solid-electrolyte interphase control, Nat. Nanotechnol. 7 (2012) 310.

[38] Y. Shi, S.L. Chou, J.Z. Wang, H.J. Li, H.K. Liu, Y.P. Wu, In-situ hydrothermal synthesis of graphene woven $\mathrm{VO}_{2}$ nanoribbons with improved cycling performance, J. Power Sources 244 (2013) 684.

\section{Figure captions}

Figure 1. XRD patterns of $\mathrm{TiO}_{2} / \mathrm{Ti}-t$ mesh $(t=0,60,180,420,600,720 \mathrm{~min})$ annealed at $500{ }^{\circ} \mathrm{C}$.

Figure 2. FESEM images of $\mathrm{TiO}_{2} / \mathrm{Ti}$ mesh prepared by anodization in EG electrolyte containing $0.25 \mathrm{wt} \% \mathrm{NH}_{4} \mathrm{~F}$ with different anodization processing times: a) 0 min; b) $60 \mathrm{~min}$; c) $180 \mathrm{~min}$; d) $420 \mathrm{~min}$; e) $600 \mathrm{~min}$; f) $720 \mathrm{~min}$. The corresponding cross-sections of $\mathrm{TiO}_{2}$ nanotubes on Ti mesh are shown in the insets. 
Figure 3. (a) Geometric parameters of $\mathrm{Ti}$ mesh and $\mathrm{TiO}_{2} / \mathrm{Ti}$ mesh obtained with anodization in EG electrolyte containing $0.25 \mathrm{wt} \% \mathrm{NH}_{4} \mathrm{~F}$. (b) Length and diameter parameters of $\mathrm{TiO}_{2} / \mathrm{Ti}$ mesh versus anodization processing time. (c) FESEM image of single wire of mesh from $\mathrm{TiO}_{2} / \mathrm{Ti}-600 \mathrm{~min}$ (cross-section); high magnification images of (d) $\mathrm{TiO}_{2}$ nanotube and (e) $\mathrm{Ti}$ wire for selected areas in (c).

Figure 4. High magnification FESEM images of $\mathrm{TiO}_{2} / \mathrm{Ti}$ mesh prepared by anodization in EG electrolyte containing 0.25 wt $\% \mathrm{NH}_{4} \mathrm{~F}$ : a) cross-sectional image of $\mathrm{TiO}_{2}$ nanotubes from $\mathrm{TiO}_{2} / \mathrm{Ti}-60$ min mesh; b) cross-sectional image of $\mathrm{TiO}_{2}$ nanotubes from $\mathrm{TiO}_{2} / \mathrm{Ti}-600 \mathrm{~min}$ mesh.

Figure 5. Electrochemical behaviour of the $\mathrm{TiO}_{2} / \mathrm{Ti}-60 \mathrm{~min}$ mesh and $\mathrm{TiO}_{2} / \mathrm{Ti}-600 \mathrm{~min}$ mesh electrodes: (a, b) cyclic voltammograms for the first 5 cycles at a scan rate of $0.1 \mathrm{mV} \mathrm{s}^{-1}$; (c, d) $5^{\text {th }}$ cycle discharge and charge curves at different current densities from $50 \mu \mathrm{A} \mathrm{cm}{ }^{-2}$ to $1000 \mu \mathrm{A} \mathrm{cm} \mathrm{cm}^{-2}$; (e) cycling performance at $50 \mu \mathrm{A} \mathrm{cm}$; (f) rate capability at different current densities.

Figure 6. (a) Impedance plots of the $\mathrm{TiO}_{2} / \mathrm{Ti}-60$ min mesh and $\mathrm{TiO}_{2} / \mathrm{Ti}-600$ min mesh anodes after cycling over 10 cycles at a discharge potential of $1.7 \mathrm{~V} \mathrm{vs}$. $\mathrm{Li} / \mathrm{Li}^{+}$at $25{ }^{\circ} \mathrm{C}$ at frequencies from $100 \mathrm{kHz}$ to $10 \mathrm{mHz}$. The equivalent circuit is shown in the inset. (b) Real part of the complex impedance versus $\omega^{-1 / 2}$ at $25^{\circ} \mathrm{C}$ at a discharge potential of $1.7 \mathrm{~V}$ vs. $\mathrm{Li} / \mathrm{Li}^{+}$.

Figure 7. FESEM images of $\mathrm{TiO}_{2} / \mathrm{Ti}$ mesh after 100 cycles: (a) top view of theTiO $/ \mathrm{Ti}$ 60min mesh; (b) cross-sectional image of the $\mathrm{TiO}_{2} / \mathrm{Ti}-60 \mathrm{~min}$ mesh; (c) high magnification image of the $\mathrm{TiO}_{2}$ nanotubes from (b); (d) top view of the $\mathrm{TiO}_{2} / \mathrm{Ti}-600 \mathrm{~min}$ mesh; (e) crosssectional image of the $\mathrm{TiO}_{2} / \mathrm{Ti}-600$ min mesh; (f) high magnification image of $\mathrm{TiO}_{2}$ nanotubes from (e). 